\title{
DOSSIER
}

\section{Vrouwen en gender in de politiek: er valt nog een wereld te winnen}

\author{
Cody Hochstenbach \& Claartje Brons*
}

\section{Introductie}

In 2019 werd aandacht besteed aan honderd jaar actief vrouwenkiesrecht in Nederland. In die honderd jaar is veel vooruitgang geboekt, bijvoorbeeld wanneer wij kijken naar de vertegenwoordiging van vrouwen in de politiek. Eind jaren zestig was nog geen 10 procent van de Tweede Kamerleden vrouw, tegenwoordig is dat ongeveer 33 procent. Deze cijfers maken ook gelijk duidelijk dat er nog een wereld te winnen valt als we het hebben over gendergelijkheid. Onder burgemeesters, gemeenteraadsleden en provinciale statenleden ligt het aandeel vrouwen bovendien nog lager. Eind 2019 bleek zelfs dat Nederland behoorlijk is gezakt op de Global Gender Gap Index, een maatstaf voor gendergelijkheid. Waar andere landen stappen vooruit maken, stagneert de situatie in Nederland en is de politieke representatie van vrouwen in de Tweede Kamer zelfs verslechterd.

De structurele ondervertegenwoordiging van vrouwen is op een aantal vlakken problematisch. Allereerst laat het zien dat vrouwen nog steeds minder kansen krijgen dan mannen, onder meer als gevolg van discriminatie, machtsongelijkheid en ingesleten sociale en maatschappelijke barrières. Het staat op gespannen voet met idealen van gendergelijkheid en rechtvaardigheid. Bovendien is de politiek er voor iedereen, en zou daarom ook door iedereen moeten zijn. Het is belangrijk om je te kunnen herkennen in politici, en het gevoel te hebben dat zij jouw belangen begrijpen en daar voor opkomen. Het is funest als je je niet kunt herkennen in de politici die zogenaamd namens jou beslissingen maken. Oude mannen in pakken die beslissen over abortus, eigenlijk is dat heel gek (Van de Beek, 2018). De ondervertegenwoordiging van vrouwen is ook maatschappelijk een probleem. Het suggereert dat er sprake is van onbenut potentieel, dat niet al het talent een kans krijgt tot wasdom te komen. Vrouwen brengen bovendien andere perspectieven en ervaringen met zich dan mannen (Mügge, Van der Pas \& Van de Wardt, 2019). Dit verrijkt het politieke debat en de politieke besluitvorming. Of beter geformuleerd: een oververtegenwoordiging van mannen die bijna allemaal op elkaar lijken verschraalt de politiek.

Genoeg redenen dus om te blijven strijden voor een gelijkwaardigere genderverdeling in de politiek. Minister van Binnenlandse Zaken Kajsa Ollongren (D66) denkt er ook zo over en kwam daarom medio 2019 met een Kamerbrief om de

* Dr. Cody Hochstenbach is redactielid van Beleid en Maatschappij. Dr. Claartje Brons is redactielid van Beleid en Maatschappij. 
vertegenwoordiging van vrouwen in de politiek te verbeteren. In deze brief formuleert zij het als haar verantwoordelijkheid 'om te voorzien in randvoorwaarden die politieke participatie zo laagdrempelig en toegankelijk mogelijk maken voor iedereen' (Ollongren, 2019, 3). Ze stelt een aantal maatregelen voor die gericht zijn op inclusieve selectieprocedures, het actief werven van vrouwen voor politieke functies, en goede toerusting en ondersteuning in het politieke ambt te verzorgen.

In dit Dossier gaan verschillende inspirerende auteurs in op de positie van vrouwen en gender in de (Nederlandse) politiek. Zij doen dit vanuit verschillende invalshoeken, op basis van hun wetenschappelijke onderzoek of hun eigen werkzaamheden rond dit thema. Wat hen bindt, is dat zij vanuit een feministische benadering werken. Volgens hoogleraren Brooke Ackerly en Jacqui True (2018) kenmerkt een feministische onderzoeksmethodologie zich onder andere door het uitdagen van vanzelfsprekendheden en vooroordelen in bestaande kennis. Zo worden blinde vlekken en kennishiaten zichtbaar. Bestaande kennis is immers niet zomaar tot stand gekomen, maar is afhankelijk van wie wat doet, waar en op welke manier. Het reflecteert daarmee machtsstructuren. Een feministische benadering houdt daarom niet alleen de kennisproductie maar ook de kennisproducenten kritisch tegen het licht. Wiens stemmen bepalen het (wetenschappelijke en publieke) debat, en wie wordt juist niet of nauwelijks gehoord? Ook is een feministische benadering normatief betrokken bij de strijd naar (gender)rechtvaardigheid en gelijkheid.

\section{Het goedpraten van structurele ongelijkheid}

De structurele ongelijkheid in man-vrouwverhoudingen in politieke functies wordt veelal op verschillende manieren goedgepraat, zonder daarbij aandacht te besteden aan bewuste en onbewuste discriminatie, machtsverhoudingen, belemmerende structuren, en gendered normen en verwachtingspatronen. Johanna Kantola en Lise Rolandsen Agustín (2019) identificeren op basis van hun onderzoek naar het Europees Parlement verschillende vertogen waarmee ongelijke verhoudingen worden goedgepraat of verklaard. Een terugkerend vertoog is dat gendergelijkheid al bereikt zou zijn. Zo zouden politieke partijen mannen en vrouwen gelijke kansen bieden. We zouden kortom te maken hebben met een niet bestaand schijnprobleem. Dit vertoog strookt echter niet met het feit dat vrouwen structureel ondervertegenwoordigd blijven, waar weer andere verklaringen voor gesuggereerd worden.

Een veel aangehaalde verklaring is dat ongelijke verdelingen de uitkomst zijn van individuele keuzes. Mannen en vrouwen zouden simpelweg andere keuzes maken. Denk bijvoorbeeld aan het idee dat vrouwen minder bereid zouden zijn een zware (politieke) baan op zich te nemen, zeker wanneer er kinderen in het spel zijn. De oplossing ligt volgens dit perspectief bij de vrouwen, zij zouden zelf hun plek moeten opeisen en verantwoordelijkheid nemen. Deze steevast terugkerende redenering is problematisch omdat het structurele ongelijkheden individualiseert. Het is zeker waar dat vrouwen en mannen op dit moment andere keuzes maken. Deze 
keuzes staan echter niet op zichzelf, maar komen tot stand binnen een bestaande sociale context. Zo zijn er sociale structuren die vooral voor vrouwen belemmeringen opwerpen, zoals al die bedrijfsculturen waar mannen de standaard zijn en waar mannelijke sollicitatiecommissies mannelijke sollicitanten aannemen en onder elkaar in overwegend mannelijke netwerken opereren. Het gaat ook om heersende sociale normen, bijvoorbeeld over taakverdelingen binnen het huishouden. Bepaalde keuzes worden meer geaccepteerd en zijn de standaard, terwijl andere keuzes als afwijkend worden gezien of helemaal niet worden besproken. Als er weinig vrouwelijke rolmodellen politiek actief zijn, zullen minder meisjes en jonge vrouwen geïnspireerd raken zelf de politiek in te gaan. Alles afschuiven op individuele keuzevrijheid negeert het bestaan van deze hardnekkige sociale structuren. Het negeert dat het om macht en machtsstructuren gaat, en dat macht bevochten wordt.

Een ander veelgehoord argument is dat het helemaal niet gaat om gendergelijkheid, maar om 'kwaliteit', het kiezen van de beste mensen. Als dat alleen maar mannen oplevert, so be it. Daarmee wordt er al te makkelijk van uitgegaan dat vrouwen simpelweg minder te bieden hebben in de politiek. Dit argument is alleen steekhoudend als het huidige systeem wél een neutrale is, waarin geen onterechte bevoordeling plaatsvindt en steevast de beste mensen uitgekozen worden. Momenteel is echter sprake van een sociale context die bepaalde groepen - vooral witte mannen - flink bevoordeelt ten opzichte van anderen. Veel vrouwen krijgen bovendien te maken met genderstereotyperingen. Respondenten in het onderzoek van Kantola en Rolandsen Agustín naar het Europese Parlement merken op dat vrouwen, en dan vooral jonge vrouwen, minder snel als expert gezien worden. Zeker wanneer het gaat om sommige, zogenaamde 'harde' thema's als economie en financiën. Vrouwen zouden beter zijn in zachtere onderwerpen. Dergelijke stereotypen en gendered verwachtingspatronen belemmeren vrouwen in het bemachtigen van belangrijke politieke functies.

\section{Perspectieven op gender en politiek}

Gender en politiek is een zeer breed thema dat je vanuit verschillende perspectieven en op uiteenlopende manieren kunt onderzoeken (zie Paxton, Kunovich \& Hughes, 2007). Het gaat om zo veel meer dan het tellen van het aantal vrouwen en mannen in de politiek. In 2018 werd de European Journal of Politics and Gender gelanceerd, een academisch tijdschrift geheel gewijd aan dit thema. Dit tijdschrift beschouwt gender als 'een politiek fenomeen dat machtsrelaties vormgeeft. Gender is contextueel en wordt beïnvloedt door meerdere sociale categorieën en identiteiten' (Ahrens e.a., 2018, 5). Gender helpt processen van politieke in- en uitsluiting bloot te leggen en begrijpen (idem). In het allereerste nummer van dit tijdschrift onderscheiden Ackerley en True (2018) de volgende vier perspectieven op gender en politiek.

Ten eerste is daar het thema 'vrouwen in de politiek'. Hierbij gaat het bijvoorbeeld om de vertegenwoordiging van vrouwen in de politiek, maar ook om de verschillende thema's die mannen en vrouwen (en niet-binaire personen) op de agenda 
zetten. Studies die de structurele ondervertegenwoordiging van vrouwen - of eigenlijk oververtegenwoordiging van mannen - in kaart brengen vallen onder dit thema.

Ten tweede onderscheiden zij het thema 'gender in de politiek'. Het gaat dan bijvoorbeeld om de rollen van mannen en vrouwen in de politiek en hun uiteenlopende ervaringen. Ackerley en True geven het voorbeeld van verschillen in leiderschapsstijl. We kunnen ook denken aan het eerder aangehaalde voorbeeld dat vrouwen, zeker op sommige thema's, minder snel als expert worden gezien. Het gaat ook om ervaringen in de politiek. Zo laat Maria Kranendonk in dit Dossier zien dat het voor veel vrouwen extra lastig is een functie in de gemeenteraad te combineren met én een drukke baan én het opvoeden van kinderen. De ervaringen van vrouwen hangen in dit geval samen met dominante rolverdelingen in het huishouden en verwachtingspatronen daarover.

Ten derde is er de 'gender van politiek', waarbij het gaat om de ongelijke invloed van veel politieke beslissingen op mannen en vrouwen. Deze genderongelijke uitwerking kan indirect en wellicht onbedoeld zijn. Een verlaging van de hoogste belastingtarieven zal bijvoorbeeld vooral mannen bevoordelen, omdat hun inkomen gemiddeld hoger is. De gendered invloed van politieke beslissingen kan ook een stuk directer en explicieter, bijvoorbeeld wanneer het gaat om thema's als het recht op abortus, vrouwenquota in het bedrijfsleven of het erkennen van identiteiten die buiten de nauwe man-vrouwdichotomie vallen (bijvoorbeeld door een derde geslachtsoptie toe te staan in het paspoort).

Ten vierde is er de focus op 'gendernormen en -beleid'. Onderzoek vanuit de voorgaande drie perspectieven kan een verandering van beleid, instituten en normen aanzwengelen, of op zijn minst aanzetten tot debat over zo'n verandering. Onderzoek vanuit dit perspectief richt zich op motivaties voor het veranderen van beleid en de internationale verspreiding van beleidsmaatregelen en -verandering om de participatie van vrouwen te bevorderen. Met andere woorden: hoe waait zulk beleid over van het ene naar het andere land?

Deze verschillende perspectieven zijn niet uitsluitend of uitputtend, maar maken bovenal duidelijk dat de studie van gender en politiek om veel meer gaat dan het aantal vrouwen in de politiek. Een focus op gender gaat bovendien verder dan louter geslacht. Het nodigt uit de samenhang tussen politieke in- en uitsluiting langs verschillende assen te analyseren en met elkaar in verband te brengen. Een dergelijk intersectioneel perspectief is belangrijk, omdat het de complexe samenhang tussen verschillende ongelijkheden blootlegt (zie Crenshaw, 1989). Het aantal vrouwen in de politiek is de afgelopen decennia weliswaar flink toegenomen in veel landen, waaronder Nederland, maar het gaat overwegend om vrouwen die behoren tot een witte, hoogopgeleide en heteroseksuele bovenlaag (Celis \& Lovenduski, 2018). De inbreng van vrouwen met andere achtergronden blijft achter (Celis e.a., 2014). De focus op man-vrouwongelijkheid gaat ook nog eens voorbij aan niet-binaire personen, een groep die doorgaans geheel niet vertegenwoordigd is in de politiek. 


\section{De bijdragen}

In dit Dossier presenteren wij vier bijdragen van auteurs die vanuit verschillende invalshoeken het thema gender en politiek benaderen. De aanleiding was honderd jaar actief vrouwenkiesrecht en de Kamerbrief met beleidsvoornemens die minister Kajsa Ollongren in dit kader presenteerde.

Als eerste constateren Liza Mügge en Zahra Runderkamp dat vrouwen letterlijk de tweede sekse in de politiek zijn en pleiten daarom voor actie. Zij presenteren een reeks mogelijke maatregelen die de politieke participatie van vrouwen moet verbeteren. Hierbij bespreken zij de voorstellen die minister Ollongren in haar Kamerbrief aanhaalt, maar kijken zij ook over de landsgrenzen naar voorbeelden uit andere landen.

Maria Kranendonk bespreekt in haar essay de ervaringen van vrouwen die actief zijn in de lokale politiek. Ze bespreekt barrières waar vrouwen in het bijzonder mee te maken krijgen. Gemeenteraden zijn vaak nog 'mannenbolwerken' waar vrouwen zich maar aan de mannelijke norm dienen aan te passen. Vrouwelijke respondenten in gemeenten waar de man-vrouwbalans zoek is, geven aan dat er weinig rekening met hen gehouden wordt, of dat zij zelfs met denigrerende opmerkingen te maken krijgen.

Saniye Çelik zoomt uit en verkent de genderdiversiteit in het openbaar bestuur. Diversiteitsbeleid bestaat al geruime tijd in de publieke sector en kan handvaten bieden voor het bevorderen van de genderdiversiteit in de politiek. Çelik analyseert de bestaande motieven voor het bevorderen van diversiteit en trekt op basis van beleidservaringen verschillende lessen voor de politiek.

Devika Partiman, oprichter van de stichting Stem op een Vrouw, stipt in haar bijdrage een belangrijke vlek aan in de viering van honderd jaar actief vrouwenkiesrecht. Zij laat zien dat de viering geheel voorbijgaat aan het feit dat dit lang niet voor alle vrouwen gold en zelfs nog steeds niet het geval is. Haar bijdrage is een goed voorbeeld dat een focus op uitsluitend vrouwen niet genoeg is, maar dat een intersectioneel perspectief centraal moet staan.

Als toegift bespreekt redactielid Yvonne La Grouw elders in dit nummer ook nog eens het boek Tegen de vrouwen van Abram de Swaan.

\section{Literatuur}

Ackerly, B., \& True, J. (2018). With or without feminism? Researching gender and politics in the 21st century. European Journal of Politics and Gender, 1 (1-2): 259-278.

Ahrens, P., Celis, K., Childs, S., Engeli, I., Evans, E., \& Mügge, L. (2018). Politics and gender: rocking political science and creating new horizons. European Journal of Politics and Gender, 1 (1-2): 3-16.

Beek, J. van de (2018). Nooit meer terug naar de breinaald. OneWorld.www.oneworld.nl/ harlot/nooit-meer-terug-naar-de-breinaald/ .

Çelik, S. (2020). Meer vrouwen in het openbaar bestuur: Lessen uit de publieke sector. Beleid en Maatschappij, 47 (1): 64-75. 
Celis, K., Erzeel, S., Mügge, L., \& Damstra, A. (2014). Quotas and intersectionality: Ethnicity and gender in candidate selection. International Political Science Review, 35 (1): 41-54.

Celis, K., \& Lovenduski, J. (2018). Power struggles: gender equality in political representation. European Journal of Politics and Gender, 1 (1-2): 149-166.

Crenshaw, K. (1989). Demarginalizing the Intersection of Race and Sex: A Black Feminist Critique of Antidiscrimination Doctrine, Feminist Theory, and Antiracist Politics." University of Chicago Legal Forum 139-167.

Kantola, J., \& Rolandsen Agustín, L. (2019). Gendering the Representative Work of the European Parliament: A Political Analysis of Women MEP's Perceptions of Gender Equality in Party Groups. JCMS: Journal of Common Market Studies, 57 (4): 768-786.

Kranendonk, M. (2020). 'Old boys networks' in het lokale politieke bestuur. Beleid en Maatschappij, 47 (1): 55-63.

Mügge, L.M., Pas, D.J. van der, \& Wardt, M. van de (2019). Representing their own? Ethnic minority women in the Dutch Parliament. West European Politics, 42 (4): 705-727.

Mügge, L. \& Runderkamp, Z. (2020). Politiek van ons allemaal: Reactie op de Kamerbrief van Minister Ollongren over vrouwen in het openbaar bestuur. Beleid en Maatschappij, 47 (1): 47-55.

Ollongren, K. (2019). Beleidsreactie rondetafelgesprek vrouwen in het openbaar bestuur. Den Haag: Ministerie van Binnenlandse Zaken en Koninkrijksrelaties.

Partiman, D. (2020). Er bestaat niet zoiets als 100 jaar vrouwenkiesrecht in Nederland. Beleid en Maatschappij, 47 (1): 76-79.

Paxton, P., Kunovich, S., \& Hughes, M.M. (2007). Gender in politics. Annual Review of Sociology, 33: 263-284. 